УДК 338.45:658.14.011.1

DOI: https://doi.org/10.32851/2708-0366/2020.3.11

Макаренко С.М.

кандидат економічних наук, доцент,

Херсонський державний університет

ORCID: https://orcid.org/0000-0001-9929-8967

Makarenko Serhii

Kherson State University

\title{
ОСОБЛИВОСТІ ІННОВАЦІЙНОГО РОЗВИТКУ ПРОМИСЛОВИХ ПІДПРИЄМСТВ В УМОВАХ ДІДЖИТАЛІЗАЦІЇ
}

\section{FEATURES OF INNOVATIVE DEVELOPMENT OF INDUSTRIAL ENTERPRISES IN THE CONDITIONS OF THE DIGITALIZATION}

У статті проведено аналіз та здійснено визначення ефективних напрямів співпраці органів державної влади, місиевого самоврядування та промислових підприємств для активізації інноваційної діяльності. Обгрунтовано, щчо одним із найважливіиих факторів підвищення ефективності господарської діяльності й максимізації вірогідності залучення інвестицій є забезпечення економічного і раціонального використання виробничих ресурсів иляхом перманентного впровадження інноваційних технологій, нових проєктних, конструкторських і технологічних рішень. Виявлено, шзо в умовах зростання загального обсягу видатків на проведення превентивних дій щуодо унеможливлення розповсюдження респіраторної хвороби COVID-19, для втримання наявних позицій на ринку кінцевої продукції та зростання рівня конкурентоспроможності підприємства взагалі необхідно активізувати співпрацюю органів влади й бізнесу в частині надання додаткових податкових преференщій під час закупівлі спеціалізованого інноваційного обладнання. Доведено необхідність розроблення комплексу заходів для обірунтування доиільності надання податкових преференцій та усунення можливих зловживань з боку суб 'єктів господарювання, у тому числі шляхом визначення інтегрального показника конкурентоспроможності підприємства в динаміці останніх років.

Ключові слова: інновації, менеджмент, інвестииії, органи влади, інтегральний показник конкурентоспроможності, діджиталізація.

В статье проведен анализ и осущуествлено определение эффективных направлений сотрудничества органов государственной власти, местного самоуправления и промышленных предприятий для активизации инновационной деятельности. Обосновано, что одним из важнейших факторов повышения эффективности хозяйственной деятельности и максимизации вероятности привлечения инвестиций является обеспечение экономического и рационального использования производственных ресурсов путем перманентного внедрения инновационных технологий, новых проектных, конструкторских и технологических решений. Выявлено, что в условиях роста общего объема расходов на проведение превентивных действий по предотвращению распространения респираторной болезни COVID-19 для удержания имеющихся позиций на рынке конечной продукиии и роста уровня конкурентоспособности предприятия в целом необходимо активизировать сотрудничество органов власти и бизнеса в части предоставления дополнительных налоговых преференций при закупке специализированного инновационного оборудования. Доказана необходимость разработки комплекса мероприятий для обоснования ичелесообразности предоставления налоговых преференичий и устранения возможных злоупотреблений со стороны субъектов хозяйствования, в том числе путем определения интегрального показателя конкурентоспособности предприятия в динамике последних лет.

Ключевые слова: инновации, менеджмент, инвестиции, органь власти, интегральный показатель конкурентоспособности, диджитализация. 
The purpose of the article is to Identification of effective areas of cooperation between public governments, local governments and industrial enterprises to intensify innovation. A systematic approach, comparison, grouping, generalization, and methods of economic analysis were applied in order to solve these tasks. The method of assessing the effectiveness of enterprise management based on the method of taxonomic analysis is used. The analysis of the innovative activity of domestic industrial enterprises shows a low level of financial resources for the purchase of machinery, equipment, software, as well as research and development. It is substantiated that one of the most important factors to increase the efficiency of economic activity and maximize the probability of attracting investment is to ensure economic and rational use of production resources through the permanent introduction of innovative technologies, new design, engineering and technological solutions. It was found that in the context of increasing total expenditures for preventive measures to prevent the spread of respiratory disease COVID-19, to maintain existing positions in the final product market and increase the level of competitiveness of the enterprise in general it is necessary to intensify cooperation between government and business. purchase of specialized innovative equipment. The need to develop a set of measures to justify the feasibility of tax incentives and eliminate possible abuses by businesses, including by determining the integrated indicator of the competitiveness of the enterprise in the dynamics of recent years. The approach of interaction of public authorities, local government and business for introduction of innovative technologies in the course of economic activity of the industrial enterprises is offered, taking into account results of definition of an integral indicator of competitiveness of the enterprise in dynamics of the last reporting periods. The provided recommendations will allow not only to substantiate the process of providing tax benefits to business entities, but also to determine the integrated indicator of the competitiveness of the enterprise in the dynamics and weaknesses of the economic process.

Key words: innovations, management, investments, government, integrated competitiveness indicator, digitalization.

Постановка проблеми. Розвиток економіки на інноваційних засадах є чинником підвищення конкурентоспроможності підприємства та країни взагалі на світовому ринку і розглядається як одне 3 першочергових завдань для органів влади. У числі пріоритетних напрямів розвитку економіки є ліквідація правових бар'єрів, що перешкоджають впровадженню провідних інноваційних технологій, створення опорної інфраструктури - ліній зв'язку, центрів зберігання і обробки даних; вдосконалення системи освіти, включаючи забезпечення загальної цифрової грамотності; запуск інструментів підтримки вітчизняних компаній, які $€$ центрами формування компетенцій у сфері цифрових та інших наскрізних технологій. В умовах перманентного зростання вартості ресурсів утримати наявні позиції та підвищити загальний рівень конкурентоспроможності зможе лише те підприємство, яке зуміє налагодити тісний взаємозв'язок з органами державної влади, місцевого самоврядування в частині отримання додаткових фінансових ресурсів та пільг для закупівлі і впровадження провідних інноваційних технологій та залучити потенційного інвестора для модернізації виробничого комплексу і розвитку суб'єкта господарювання загалом [8]. Зазначене визначило актуальність теми дослідження, його завдання та зміст.

Аналіз останніх досліджень і публікацій. Питання розроблення стратегії інноваційного розвитку підприємства отримали широке трактування та дослідження, зокрема у роботах Л.Л. Антонюк, А.М. Поручник, В.С. Савчук [2], Л.В. Білозорова [3], К.Ю. Вергала [4], Б. Грепона [13], С.Ю. Ілляшенка [5] та інших. Сучасні проблеми інвестиційно-інноваційного розвитку підприємств активно обговорюються у працях І.П. Андрушкова, О.Д. Вовчак, Н.М. Рущишина [1], С.О. Кушнір, Л.М. Рудь [6], Н.М. Олійник, С.А. Рибачка [8], Н.М. Олійник, Л.О. Корчевської [9] та інших. Незважаючи на вагомі напрацювання, залишаються проблеми, що потребують додаткового наукового аналізу, особливо щодо удосконалення державної інвестиційної політики як основи впровадження інноваційних технологій на вітчизняних підприємствах.

Малодослідженими та не розкритими у періодичних літературних виданнях залишаються питання, пов'язані з налагодженням взаємодії підприємств і державних 
інституцій як складника залучення додаткових інвестиційних ресурсів для впровадження інноваційних технологій у процес господарської діяльності шляхом розроблення обгрунтованого науково-методичного підходу.

Формулювання цілей статті. Метою статті є визначення ефективних напрямів співпраці органів державної влади, місцевого самоврядування та промислових підприємств для активізації інноваційної діяльності.

Виклад основного матеріалу. У сучасних умовах ведення бізнесу особливої актуальності набуває активізація інноваційних процесів на рівні підприємств як складників економічного життя регіону та країни взагалі. У майбутньому наявні конкурентні переваги будуть втрачені тими підприємствами, які не змогли оцінити важливість безупинної і багатоаспектної реалізації інновацій [8]. Особливо зазначене актуальне для підприємств промислової галузі, де рівень конкурентної боротьби на ринку кінцевої продукції щороку зростає. Водночас, незважаючи на важливість інноваційно-активної господарської діяльності, загальний обсяг витрат на впровадження інновацій на вітчизняних промислових підприємствах за підсумками 2018 року становив лише 12,2 млрд грн., що, навіть без урахування рівня інфляції та інших економічних чинників, свідчить про зменшення обсягів фінансування на 47,6\% порівняно з 2016 роком та на 15\% порівняно з 2011 роком [12].

Під час дослідження напрямів фінансування було встановлено, що протягом 2011-2018 років найбільша питома вага витрат на проведення досліджень та розробок спостерігалася у 2018 році (26,34\% від загальної суми витрат). Водночас результати раніше проведених досліджень [14] свідчать, що значна питома вага виконаних науково-дослідних робіт має суто теоретичний характер і отримані результати не можуть бути впроваджені у господарську діяльність вітчизняних підприємств. Так, під час обчислення коефіцієнтів парної кореляції був виявлений від'ємний зв'язок між загальним обсягом валового внутрішнього продукту та кількістю осіб, які закінчили докторантуру. Зазначене можна аргументувати тим, що в сучасних умовах розвитку науки в Україні захист дисертаційних робіт на здобуття наукового ступеня доктора наук має в більшості випадків теоретичний характер без можливого впровадження отриманих результатів у практику діяльності вітчизняних суб'єктів господарювання усіх форм власності. Як наслідок, темп зростання рівня оплати праці працівників, які успішно захистили дисертаційні роботи, набагато перевищує темп зростання продуктивності їхньої праці та ефективності діяльності. В окремих же випадках, коли у дисертаційних роботах на здобуття наукового ступеня доктора наук висвітлюються актуальні для суспільства питання та наводиться дієвий механізм їх вирішення, ще на етапі підготовки дисертаційної роботи відбувається «переманювання» докторантів до зарубіжних компаній з метою забезпечення подальшого експортування їхнього інтелектуального потенціалу за кордон [14].

Окремої уваги заслуговують питання, пов'язані 3 діджиталізацією бізнесу та придбанням машин та програмного забезпечення як складової частини активізації інноваційної діяльності. Так, питома вага витрат у загальному обсязі протягом 2011-2018 років коливалася від 58\% у 2013 році до 85,4\% у 2016 році. У 2018 році на придбання машин та програмного забезпечення було направлено 68,1\% від загального обсягу витрат на інноваційну діяльність. Водночас, за даними Державної служби статистики України [12], у 2018 році в середньому лише 89,7\% підприємств використовували комп'ютери під час забезпечення організації та проведення господарської діяльності, та лише 32,8\% найманих працівників використовували комп'ютери у своїй роботі. У переробній галузі аналогічна ситуація, і частка підприємств, що використовувала комп'ютери, становила 91,7\%, найманих працівників - 26,8\%. І це незважаючи на той факт, що у сучасних умовах ринку ефективність функціонування та конкурентоспроможність підприємства безпосередньо залежить від його інформаційного та комунікаційного потенціалів. 
Проведене дослідження також свідчить, що найбільша питома вага працівників, які у повсякденній діяльності постійно використовують комп'ютер, спостерігається у сфері ремонту комп'ютерів і обладнання зв'язку (80\%), інформації та телекомунікації $(78,7 \%)$, а також у професійній, науковій та технічній діяльності $(69,2 \%)$. Зазначене безпосередньо пов'язано зі специфікою функціонування вказаних суб'єктів господарювання.

Під час дослідження рівня діджиталізації та інноваційного розвитку промислових підприємств Херсонської області було виявлено, що у процеси господарської діяльності майже не залучаються фахівці сфери інформаційних та комунікаційних технологій, не використовуються LAN-мережі. Технічне обслуговування інфраструктури інформаційно-комунікаційних технологій, підтримка та розвиток програмного забезпечення й забезпечення захисту конфіденційної інформації здійснюється лише зі залученням фахівців зовнішніх компаній.

На прикладі ТОВ «Шкіряний завод «Платан ЛТД» (сучасне підприємство легкої промисловості, яке спеціалізується з пошиття шкіряного взуття та верхнього одягу, м. Херсон) встановлено, що власним сайтом підприємство не володіє, соціальні медіа, хмарні технології та аналіз «великих даних» не використовує у своїй діяльності. Рахунки-фактури у 100\% обсязі отримуються лише у паперовому вигляді, який непридатний для електронної обробки.

Порівняльний аналіз показників використання інформаційно-комунікаційних технологій на підприємстві зі середньоукраїнським рівнем наведено у таблиці 1. Проведені розрахунки свідчать, що ТОВ «Шкіряний завод «Платан ЛТД» за показником підключення до мережі Інтернет випереджає середньоукраїнський рівень на 14,7 відсоткових пункти. Водночас, загальна частка працівників підприємства, що використовують комп'ютер, є нижчою на 3,9 відсоткових пункти і за підсумками 2019 року становить лише $30,4 \%$.

Таблиця 1

Порівняльний аналіз показників використання інформаційно-комунікаційних технологій у 2019 році

\begin{tabular}{|c|c|c|c|}
\hline \multicolumn{1}{|c|}{ Показник } & $\begin{array}{c}\text { ТОВ } \\
\text { «Шкіряний } \\
\text { завод } \\
\text { «Платан ЛТД» }\end{array}$ & $\begin{array}{c}\text { Середній } \\
\text { показник } \\
\text { по Україні }\end{array}$ & Відхилення \\
\hline п. 1 & п. 2 & п. 3 & п. 4 = п. 2 - п. 3 \\
\hline $\begin{array}{l}\text { Частка працівників, що використовують } \\
\text { комп'ютер }\end{array}$ & 30,4 & $34,3 \%$ & $-3,9$ \\
\hline $\begin{array}{l}\text { Частка працівників, що використовують } \\
\text { комп'ютер з Інтернетом до працівників, } \\
\text { що використовують комп'ютер }\end{array}$ & $97,5 \%$ & $82,8 \%$ & 14,7 \\
\hline
\end{tabular}

Джерело: розраховано за даними ТОВ «Шкіряний завод «Платан ЛТД» та Державної служби статистики України [12]

Аналіз виробничо-збутової складової частини господарської діяльності досліджуваного об'єкта свідчить, що за споживчими та економічними параметрами продукція ТОВ «Шкіряний завод «Платан ЛТД» переважає аналогічну продукцію найближчого конкурента - ТОВ «СпецТкань». Водночас під час дослідження рівня фінансової стійкості підприємства було виявлено, що у 2019 році коефіцієнт фінансової автономії підприємства зменшився на 0,0376, а отже, збільшився на 0,505 показник залежності підприємства від зовнішніх інвесторів і кредиторів. На кожну гривню власних коштів підприємства на початок 2019 року приходилося 2,42 грн залучених коштів, на кінець 
звітного періоду - 2,92 грн. Це ще раз підтверджує про погіршення рівня фінансової стійкості ТОВ «Шкіряний завод «Платан ЛТД». Також на підприємстві відбулося зменшення рівня маневреності власного капіталу.

Враховуючи, що найбільшу питому вагу в собівартості продукції ТОВ «Шкіряний завод «Платан ЛТД» займають витрати на купівлю сировини й матеріалів, на перспективу підприємству потрібно зосередити свої зусилля на впровадженні нових прогресивних технологій щодо оптимізації їх використання (зменшити втрати сировини, матеріалів, забезпечити їх оптимальне використання без погіршення рівня якості продукції, що виробляється). Для виконання зазначеного необхідно закупити та ввести в експлуатацію нове високопродуктивне модернізоване устаткування: комплекс для швейного виробництва універсального типу; комплекс для швейного виробництва спеціального типу загальною вартістю близько 600 тис. грн. Впровадження зазначеного обладнання у виробничий процес на ТОВ «Шкіряний завод «Платан ЛТД» дасть змогу без погіршення якості продукції в середньому знизити витрати сировини та матеріалів під час виробництва рукавиць із сукна, рукавиць спеціальних зі шкіри та костюмів для сталеварів до 10\%. Зазначене забезпечить зростання рентабельності основних видів продукції за незмінної ціни реалізації в середньому на 8 відсоткових пункти. У разі співпраці підприємства й банківських установ та співфінансування проєкту у пропорції 50:50 і отримання кредитних ресурсів в обсязі 300 тис. грн. під $25 \%$ річних у діючих цінах, ставці дохідності 14\%, мінімально допустимий термін окупності інвестованих та залучених ресурсів становитиме понад 5 років. Вказане у сучасних умовах прискореного морального зносу основних фондів $є$ неприпустимим та не дозволяє підприємству втримати наявні позиції на ринку виробництва й збуту кінцевої продукції.

Для створення належних умов щодо зростання рівня інноваційної активності вітчизняного бізнесу, залучення провідних інноваційних технологій у процес господарювання, в умовах обмеженості джерел фінансування та зростання обсягу витрат на проведення превентивних дій щодо втримання розповсюдження гострої респіраторної хвороби COVID-19, доцільно забезпечити налагодження ефективної взаємодії між органами влади, місцевого самоврядування та представниками бізнесу в частині надання додаткових пільг під час закупівлі інноваційного обладнання, що не виробляється на території країни, залучення іноземного капіталу у розвиток провідних промислових підприємств. Результати проведених досліджень [8] свідчать, що відповідно до статті 18 розділу IV Закону України «Про режим іноземного інвестування» [11] (до прийняття Закону України «Про внесення змін до деяких законодавчих актів України у зв'язку з прийняттям Митного кодексу України» від 13 березня 2012 року № 4496-VI [10]) передбачалося, що майно, яке ввозиться в Україну як внесок іноземного інвестора до статутного фонду підприємств з іноземними інвестиціями (крім товарів для реалізації або власного споживання), звільняється від обкладення митом (у разі дотримання встановлених процедур). Використовуючи вищевказану законодавчу норму підприємства промисловості, у тому числі й ТОВ «Шкіряний завод «Платан ЛТД», могли не лише знизити питому вагу витрат на закупівлю сировини й матеріалів шляхом перманентного впровадження у виробництво інноваційного спеціалізованого обладнання, а й зацікавити іноземного інвестора в плідній співпраці 3 метою збільшення обсягів виробництва, впровадження інноваційних технологій, виробництва нових видів продукції, конкурентоспроможної як на внутрішньому, так і на зовнішньому ринках збуту. Зменшення вартості закупівлі вищенаведеного високопродуктивного модернізованого устаткування в середньому на $10 \%$ дасть змогу зменшити термін окупності інвестованих та кредитних ресурсів до 4 років, тим самим створивши додаткові стимули для розвитку підприємства, втримання й нарощування наявного конкурентного потенціалу і подальшого залучення іноземних інвестицій. 
Водночас в умовах обмеженого надходження податків та зборів до бюджетів всіх рівнів в умовах децентралізації та надання більших повноважень органам місцевого самоврядування необхідно додатково розробити науково-методичний підхід, що дозволить усунути можливі зловживання з боку бізнесу та надання додаткових необгрунтованих преференцій.

На першому етапі розгляду питань щодо надання додаткових податкових преференцій доцільно було б визначити інтегральний показник конкурентоспроможності підприємства та дослідити його зміну у певному часовому періоді. Для цього пропонуємо скористатися методом таксономічного аналізу. У таблиці 2 представлена узагальнена система інформаційного простору для розрахунку інтегрального показника конкурентоспроможності ТОВ «Шкіряний завод «Платан ЛТД».

Таблиця 2

Система інформаційного простору для розрахунку інтегрального показника конкурентоспроможності ТОВ «Шкіряний завод «Платан ЛТД»

\begin{tabular}{|c|c|c|c|c|c|c|c|c|}
\hline \multirow{2}{*}{ 产 } & \multirow{2}{*}{ Показник } & \multicolumn{5}{|c|}{ Роки } & \multirow{2}{*}{$\begin{array}{c}\text { Середнс } \\
\text { зна- } \\
\text { чення }\end{array}$} & \multirow{2}{*}{$\begin{array}{c}\text { Середньо- } \\
\text { квадратичне } \\
\text { відхилення }\end{array}$} \\
\hline & & 2015 & 2016 & 2017 & 2018 & 2019 & & \\
\hline A1 & $\begin{array}{l}\text { Середня продуктив- } \\
\text { ність працівника, } \\
\text { грн./год. }\end{array}$ & 94,7 & 103,4 & 108,7 & 113,6 & 124,3 & 108,94 & 9,911 \\
\hline A2 & $\begin{array}{l}\text { Коефіцієнт виконав- } \\
\text { чої дисципліни }\end{array}$ & 0,83 & 0,84 & 0,87 & 0,91 & 0,89 & 0,87 & 0,03 \\
\hline A3 & $\begin{array}{l}\text { Коефіцієнт фінан- } \\
\text { сової автономії }\end{array}$ & 0,2849 & 0,3146 & 0,3018 & 0,2924 & 0,2548 & 0,29 & 0,02 \\
\hline A4 & $\begin{array}{l}\text { Ступінь придатності } \\
\text { основних фондів, \% }\end{array}$ & 40,4 & 38,7 & 47,3 & 45,6 & 44,8 & 43,36 & 3,259 \\
\hline A5 & $\begin{array}{l}\text { Коефіцієнт надій- } \\
\text { ності управління }\end{array}$ & 0,9 & 0,81 & 0,82 & 0,84 & 0,89 & 0,85 & 0,037 \\
\hline A6 & $\begin{array}{l}\text { Частка адміністра- } \\
\text { тивного персоналу в } \\
\text { загальній кількості } \\
\text { персоналу, \% }\end{array}$ & 7,9 & 8,4 & 7,9 & 8,4 & 8,3 & 8,18 & 0,232 \\
\hline
\end{tabular}

Джерело: розраховано за даними ТОВ «Шкіряний завод «Платан ЛТД»

Стандартизовані значення показників, проміжні значення точки-еталону, евклідової відстані та інтегрального показника відображено в таблиці 3.

Проведені розрахунки свідчать, про інтегральний показник конкурентоспроможності ТОВ «Шкіряний завод «Платан ЛТД» у 2019 році зменшився на 0,08 пункта порівняно з 2018 роком та на 0,09 пункта порівняно з 2017 роком. Зазначене пов'язано передусім зі зниженням ступеня придатності основних засобів, коефіцієнтів виконавчої дисципліни та фінансової автономії, зростанням частки адміністративного персоналу. Як бачимо, крім необхідності забезпечення впровадження сучасного інноваційного обладнання керівництву ТОВ «Шкіряний завод «Платан ЛТД» необхідно також забезпечити оптимальне використання трудових ресурсів, особливо в частині встановлення обгрунтованої пропорції щодо чисельності адміністративного персоналу та персоналу, безпосередньо задіяного у виробничому процесі. Зазначене також може сприяти зростанню рівня довіри з боку виробничих працівників до керівництва підприємства, а отже, й зростанню коефіцієнта виконавчої дисципліни. 
Таблиця 3

Стандартизовані значення показників, проміжні значення точки-еталону, евклідової відстані та інтегрального показника

\begin{tabular}{|c|c|c|c|c|c|c|c|c|c|}
\hline $\begin{array}{c}\text { Стандартне } \\
\text { значення }\end{array}$ & $\mathbf{2 0 1 5}$ & $\mathbf{2 0 1 6}$ & $\mathbf{2 0 1 7}$ & $\mathbf{2 0 1 8}$ & $\mathbf{2 0 1 9}$ & $\begin{array}{c}\text { Точка } \\
\text { еталон }\end{array}$ & $\overline{\mathbf{C}_{\mathbf{0}}}$ & $\mathbf{S}_{\mathbf{0}}$ & $\mathbf{C}_{\mathbf{0}}$ \\
\hline А1 & $-1,4367$ & $-0,5590$ & $-0,0242$ & 0,4702 & 1,5497 & 1,5497 & & & \\
\hline А 2 & $-1,2695$ & $-0,9354$ & 0,0668 & 1,4031 & 0,7350 & 1,4031 & & & \\
\hline А 3 & $-0,2391$ & 1,2404 & 0,6028 & 0,1345 & $-1,7386$ & 1,2404 & & & \\
\hline А 4 & $-0,9084$ & $-1,4301$ & 1,2091 & 0,6874 & 0,4419 & 1,2091 & & & \\
\hline А5 & 1,3132 & $-1,1491$ & $-0,8755$ & $-0,3283$ & 1,0396 & 1,3132 & & & \\
\hline А6 & $-1,2094$ & 0,9503 & $-1,2094$ & 0,9503 & 0,5183 & $-1,2094$ & & & \\
\hline $\begin{array}{l}\text { Евклідова } \\
\text { відстань }\end{array}$ & 4,7681 & 5,2543 & 3,0757 & 3,1654 & 3,6013 & & 3,973 & 0,8797 & 5,7324 \\
\hline $\begin{array}{l}\text { Інтегральний } \\
\text { показник }\end{array}$ & 0,17 & 0,08 & 0,46 & 0,45 & 0,37 & & & & \\
\hline
\end{tabular}

Джерело: розраховано автором

Усунення виявлених недоліків у господарському процесі дасть змогу не лише

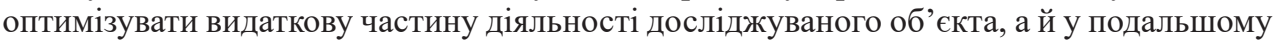
може сприяти залученню додаткових інвестиційних ресурсів у розвиток та отримання податкових пільг.

Висновки. Результати проведених досліджень свідчать про низький рівень інноваційної активності вітчизняних промислових підприємств, особливо в частині закупівлі машин, обладнання та програмного забезпечення. Також встановлено, що зростання обсягів витрат на проведення внутрішніх та зовнішніх науково-дослідних розробок не дає змоги забезпечити відповідний рівень зростання обсягів виробництва продукції, виконання робіт та надання послуг внаслідок низького рівня їх практичної придатності.

Під час дослідження рівня діджиталізації промислових підприємств Херсонської області було виявлено низький рівень залучення фахівців сфери інформаційних та комунікаційних технологій, використання LAN-мережі. На прикладі одного з провідних підприємств легкої промисловості (ТОВ «Шкіряний завод «Платан ЛТД») встановлено, що підприємство власним сайтом не володіє, соціальні медіа, хмарні технології та аналіз «великих даних» не використовує у своїй діяльності. Рахунки-фактури у $100 \%$ обсязі отримуються у паперовому вигляді, який непридатний для електронної обробки.

Для втримання наявних позицій на ринку та подальшого зростання конкурентоспроможності продукції й підприємства взагалі досліджуваному об'єкту необхідно зосередити свої зусилля на впровадженні нових прогресивних технологій щодо оптимізації використання виробничих ресурсів. Виявлено, що за сприяння органів державної влади та місцевого самоврядування в частині отримання додаткових податкових преференцій і зменшення вартості закупівлі високопродуктивного модернізованого устаткування в середньому на 10\%, термін окупності інвестованих та кредитних ресурсів зменшиться до 4 років, тим самим створивши додаткові стимули для розвитку підприємства, втримання й нарощування наявного конкурентного потенціалу та подальшого залучення іноземних інвестицій.

Запропонований науково-методичний підхід щодо визначення інтегрального показника конкурентоспроможності підприємства в динаміці останніх звітних періодів дасть змогу не лише обгрунтувати процес визначення доцільності надання податкових преференцій, а й визначити слабкі місця у господарській діяльності досліджуваного об'єкта. 


\section{Список використаних джерел:}

1. Андрушків І.П., Вовчак О.Д., Рущишин Н.М. Інвестування регіональної економіки та його ефективність в Україні : монографія. Львів : ЛКА, 2010. 192 с.

2. Антонюк Л.Л., Поручник А.М., Савчук В.С. Інновації: Теорія, механізм розробки та комерціалізації : монографія. Київ : КНЕУ, 2003. 394 с.

3. Білозор Л.В. Методологічні підходи щодо формування інноваційної продукції. Економіка АПК. 2012. № 9. С. 88-93.

4. Вергал К.Ю. Теоретико-методологічні основи розробки стратегії інноваційного розвитку підприємства. Управління розвитком. 2008. № 19. С. 27-28.

5. Ілляшенко С.Ю. Маркетинг інновацій і інновації в маркетингу : монографія. Суми : ВТД «Університетська книга», 2008. 615 с.

6. Кушнір С.О., Рудь Л.М. Інвестиційна привабливість агропромислового комплексу України: сучасний стан та перспективи. Збірник наукових праць «Проблеми системного підходу в економіці». 2017. № 1 (57). С. 42-46.

7. Лепетюха Н.В., Рудська І.О. Інтегральна оцінка ефективності функціонування підприємства. Миколаївський національний університет імені В.О. Сухомлинського. Економіка та управління підприсмствами. 2016. Випуск 14. С. 424-429.

8. Макаренко С.М., Олійник Н.М., Рибачок С.А. Удосконалення державної інвестиційної політики як основи впровадження інноваційних технологій на вітчизняних підприємствах. Економічні інноващії. Збірник наукових пращь. Одеса : Інститут проблем ринку та економіко-екологічних досліджень НАН України. № 3 (72). С. 62-70.

9. Олійник Н.М., Корчевська Л.О., Макаренко С.М. Оцінка інвестиційної складової економічної безпеки Херсонського регіону з метою залучення міжнародних проектів. Вісник Хмельницького національного університету: Економічні науки. № 1 (244). 2017. С. 130-134.

10. Про внесення змін до деяких законодавчих актів України у зв'язку з прийняттям Митного кодексу України: Закон України від 13 березня 2012 року № 4496-VI. Верховна Рада України. URL: https://zakon.rada.gov.ua/laws/show/4496-17/print (дата звернення: 12.10.2020).

11. Про режим іноземного інвестування: Закон України від 19 березня 1996 року № 93/96BP. Верховна Рада Украӥни. URL: https://zakon.rada.gov.ua/laws/show/93/96-\%D0\%B2\%D1\%80/ print (дата звернення: 12.10.2020).

12. Статистика. Державна служба статистики України. URL: http://www.ukrstat.gov.ua (дата звернення: 12.10.2020).

13. Grepon Bruno, Emmanuel Duquet. Innovation: mesunes, redements et concurrence. Econ et statist. 2004. № 275-276.

14. Makarenko S.M., Oliinyk N.M., Kazakova T. S. Improving the method approach to the rating evaluation of employees as professional career development. Baltic Journal of Economic Studies, 2018. Vol. 4, no. 5. December, pp. 179-187. URL: http://dx.doi.org/10.30525/2256-0742/2018-4-5-179-187.

\section{References:}

1. Andrushkiv I.P., Vovchak O.D., Rushchyshyn N.M. (2010) Investuvannia rehionalnoi ekonomiky ta yoho efektyvnist $v$ Ukraini [Investment into regional economy and its effectiveness in Ukraine]. Lviv: LKA. (in Ukrainian)

2. Antoniuk L.L., Poruchnyk A.M., Savchuk V.S. (2003) Innovatsii: Teoriia, mekhanizm rozrobky ta komertsializatsii [Innovations: Theory, mechanism of development and commercialization]. Kyiv: KNEU. (in Ukrainian)

3. Bilozor L.V. (2012) Metodolohichni pidkhody shchodo formuvannia innovatsiinoi produktsii [Methodological approaches to the formation of innovative products]. Ekonomika APK, no. 9, pp. 88-93.

4. Verhal K.Yu. (2008) Teoretyko-metodolohichni osnovy rozrobky stratehii innovatsiinoho rozvytku pidpryiemstva [Theoretical and methodological bases of development of strategy of innovative development of the enterprise]. Upravlinnia rozvytkom, no. 19, pp. 27-28.

5. Illiashenko S.Yu. (2008) Marketynh innovatsii i innovatsii v marketynhu: monohrafiia [Marketing innovation and innovation in marketing]. Sumy: VTD «Universytetska knyha». (in Ukrainian)

6. Kushnir S.O., Rud L.M. (2017) Investytsiina pryvablyvist ahropromyslovoho kompleksu Ukrainy: suchasnyi stan ta perspektyvy [Investment attractiveness of the agroindustrual complex Ukraine: current state and prospects]. Zbirnyk naukovykh prats «Problemy systemnoho pidkhodu $v$ ekonomitsi», vol. 1, no. 57, pp. 42-46. 
7. Lepetiukha N.V., Rudska I.O. (2016) Intehralna otsinka efektyvnosti funktsionuvannia pidpryiemstva [The Integral Estimation Of The Enterprise Functioning]. Nikolaev National University of VA Sukhomlinsky. Business Economics and Management, vol. 14, pp. 424-429.

8. Makarenko S.M., Oliinyk N.M., Rybachok S.A. (2019) Udoskonalennia derzhavnoi investytsiinoi polityky yak osnovy vprovadzhennia innovatsiinykh tekhnolohii na vitchyznianykh pidpryiemstvakh [Improvement of state investment policy as the basis of implementation of innovative technologies on domestic enterprises]. Ekonomichni innovatsii. Zbirnyk naukovykh prats. Odesa: Instytut problem rynku ta ekonomiko-ekolohichnykh doslidzhen NAN Ukrainy. no. 3 (72), pp. 62-70.

9. Oliinyk N.M., Korchevska L.O., Makarenko S.M. (2017) Otsinka investytsiinoi skladovoi ekonomichnoi bezpeky Khersonskoho rehionu z metoiu zaluchennia mizhnarodnykh proektiv [Evaluation of investment component of the economic security of Kherson region to attract international projects]. Visnyk Khmelnytskoho natsionalnoho universytetu: Ekonomichni nauky. Khmelnytskyi. vol. 1, no. 244. pp. 130-134.

10. Pro vnesennia zmin do deiakykh zakonodavchykh aktiv Ukrainy u zviazku z pryiniattiam Mytnoho kodeksu Ukrainy [On Amendments to Certain Legislative Acts of Ukraine in connection with the adoption of the Customs Code of Ukraine] (2012): Zakon Ukrainy vid 13 bereznia 2012 roku № 4496-VI. Verkhovna Rada Ukrainy. Available at: https://zakon.rada.gov.ua/laws/show/4496-17/ print (accessed 12 October 2020).

11. Pro rezhym inozemnoho investuvannia [On the regime of foreign investment]: Zakon Ukrainy vid 19 bereznia 1996 roku № 93/96-VR. Verkhovna Rada Ukrainy. Available at: https://zakon.rada.gov.ua/ laws/show/93/96-\%D0\%B2\%D1\%80/print (accessed 12 October 2020).

12. Statystyka. Derzhavna sluzhba statystyky Ukrayiny [Statistics. State Statistics Service of Ukraine]. Available at: http://www.ukrstat.gov.ua (accessed 12 October 2020).

13. Grepon Bruno, Emmanuel Duquet (2004) Innovation: mesunes, redements et concurrence. Econ et statist, no. 275-276.

14. Makarenko S.M., Oliinyk N.M., Kazakova T.S. (2018) Improving the method approach to the rating evaluation of employees as professional career development. Baltic Journal of Economic Studies, vol. 4, no. 5. December, pp. 179-187. Available at: http://dx.doi.org/10.30525/2256-0742/2 018-4-5-179-187. 